\title{
Teat Morphological and Milk Somatic Cell Comparison between Zebu Cattle (Deoni) and HF Crossbred (Bos taurus $x$ Bos indicus)
}

\author{
M. Mohan ${ }^{1 *}$, DN. Das ${ }^{1}$, PB. Nandini ${ }^{2}$ and K. P. Ramesha ${ }^{1}$ \\ ${ }^{1}$ Divison of Animal genetics and breeding, ICAR-NDRI, Bengaluru, India \\ ${ }^{2}$ Department of animal genetics and breeding, ICAR-NDRI, Karnal, India \\ *Corresponding author
}

\begin{abstract}
A B S T R A C T
\section{Keywords}

Teats, Milk fat, Milk protein, Mammary infection

Article Info

Accepted:

22 June 2020

Available Online:

10 July 2020

Post influence of operation flood made India a leading global milk producer at the expense of decline in indigenous cattle population replaced by high milk producing exotic crossbred cattle. Recent times exotic crossbreds often suffer of mammary gland infection in compared to indigenous population results in economic loses and increased cost of production. With an aim to understand the simple morphology of teat and milk quality of indigenous cattle and exotic crossbred we formulated the following experiment, in which HF crossbred with greater teat diameter are susceptible to mammary infection compared indigenous cattle with smaller diameter. The greater distance difference between front and rear teat of HF crossbred might accounts for its high milk holding capacity but it doesn't show any significant difference of mean teat day milk yield compared to Deoni. Low milk somatic cell count of Deoni could be a reason for low incidence of mammary infection in compared to HF crossbred.
\end{abstract}

\section{Introduction}

India leads in global milk production with 187.7 million tonnes during 2018-19 with an annual growth rate of 6.4 per cent (NDDB, 2019) in which cattle contributes 45.0 per cent. This achievement is made possible only by means of selective breeding for milk production traits and promoting crossbreeding programme. Improvement of crossbred cattle was an important reason for this growth rate and self-sustainability of milk in our country. This was also reflected in $20^{\text {th }}$ Livestock census, there was about 6.00 per cent decrease in indigenous cattle population, whereas crossbred's population was increased by 26.9 per cent in comparison to $19^{\text {th }}$ livestock census. The cause for decrease in population size of indigenous cattle is mainly due to milk production difference between these breeds. An average per day milk yield of crossbred's ranges from 6.78 to $10 \mathrm{~kg}$ whereas most of indigenous cattle give average per day milk yield ranging from 2.5 to $4.0 \mathrm{~kg}$ (DAHD, 2020). This economic perspective would probably cause of increase in crossbred population compared to indigenous cattle population. Along with increasing milk production India also faces economic loses from farmer side due to mastitis annually 2.37 
thousand crore rupees (Sinha et al., 2014). Mastitis is a multi-factorial condition caused by breed difference, morphological difference within individual, susceptibility to pathogen, immunity status of animal and soon (Joshi and Gokhale, 2006). The purpose for this study is to find whether morphological difference accounts for incidence for mammary gland infection, along with milk quality variation between crossbred and indigenous cattle.

\section{Materials and Methods}

The study was carried out in Livestock Research Centre, National Dairy Research Institute, Bengaluru. Prior to actual analysis screening of all lactating animals done, out of which only healthy animals are selected for this experiment Deoni $(n=20)$ and HF crossbred $(n=22)$ cows to nullify biased comparison of healthy and apparently healthy. Milk quality analysis includes milk somatic cells estimation using De Laval direct cell counter, milk fat percentage using conventional volumetric Gerber's fat estimation and milk protein percentage using estimation of nitrogen content in milk using kjeldahl's method. Teat morphology measurements were taken classifying as Front Teat Length (FTL), Front Teat Diameter (FTD), Rear Teat Diameter (RTL), Rear Teat Diameter (RTD), Distance between two Front Teat (DFT), Distance between two Rear Teat (DRT) and Distance between Front and Rear Teat (DFRT). Data analysis was carried out using SPSS software.

\section{Results and Discussion}

\section{Milk Somatic cell count (SCC)}

Somatic cell count is golden standard test to screen healthy and infected animals with sub clinical mastitis. Many reports indicated that Somatic cell count is associated with milk yield and udder health of cattle, the increase in cell count causes increase in infection and correspondingly reduces milk yield (Hand et al., 2012). In the present only healthy animal's somatic cell count was taken into account to estimate average SCC of Deoni and HF crossbred. The result showed that Deoni's milk had significantly lesser somatic cell count than HF crossbred's milk (Table.1). But the previous study on season-wise change of SCC average revealed higher values than this present study values (Mundhe et al., 2018), because in that previous investigation both infected and healthy animals were considered.

\section{Teat morphological traits measurement}

In the study we observed both breeds front teat length was greater than rear teat length, but in terms of diameter rear hold increased circumference than front teat. There is an increased teat length and significant reduction in teat diameter along with distance between front two teats after milking than before milking between Deoni and HF crossbred cows. These results were correlated with finding of Minogoas et al., (2017).

The variance analysis of each parameter is shown in Table. 2 and also observed a significant difference in teat diameter and distance between front and rear teats of HF crossbreds than Deoni Cows. Before and after milking teats measurements shows greater deviation in all parameters especially $\mathrm{HF}$ crossbred's front teat diameter, distance between front teat and also distance between front and rear teat deviates significantly in comparison with Deoni, earlier reports also showed similar significant difference in after milking teat measurement between two milking groups high vs low milk producing in Brown SwissGir cattle and Nili-ravi buffalo respectively (Tilki et al., 2005; Patel et al., 2016 \& Chandrasekar et al., 2016). 
Table.1 LS Mean \pm S.E Somatic Cell Count in Deoni and HF Crossbred

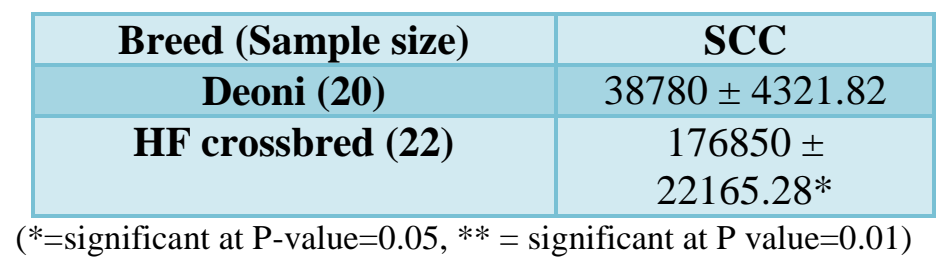

Table.2 LS Mean \pm S.E of teat measurement in Deoni and HF crossbreeds before and after milking

\begin{tabular}{|c|c|c|c|c|c|c|c|c|c|}
\hline \multirow[t]{2}{*}{ Breeds } & \multicolumn{9}{|c|}{ Teat Measurement (mm) } \\
\hline & FTL & \multicolumn{2}{|l|}{ FTD } & RTL & RTD & DFT & \multicolumn{2}{|c|}{ DFRT } & DRT \\
\hline \multicolumn{10}{|c|}{ Before Milking } \\
\hline Deoni (20) & $\begin{array}{c}68.06 \pm \\
3.31\end{array}$ & \multicolumn{2}{|c|}{$\begin{array}{l}78.8 \pm \\
3.62\end{array}$} & $\begin{array}{c}57.6 \pm \\
2.49\end{array}$ & $\begin{array}{c}84.8 \pm \\
6.45\end{array}$ & $\begin{array}{c}98.66 \pm \\
4.47\end{array}$ & \multicolumn{2}{|c|}{$44 \pm 3.05$} & $\begin{array}{l}73 \pm \\
4.13\end{array}$ \\
\hline $\begin{array}{l}\text { HF crossbred } \\
\text { (22) }\end{array}$ & $\begin{array}{c}72.95 \pm \\
3.13\end{array}$ & \multicolumn{2}{|c|}{$\begin{array}{c}93.25 \pm \\
5.25^{*}\end{array}$} & $\begin{array}{c}56.35 \pm \\
2.23\end{array}$ & $\begin{array}{c}94.75 \pm \\
3.67 *\end{array}$ & $\begin{array}{c}133 \pm \\
5.33 * *\end{array}$ & \multicolumn{2}{|c|}{$\begin{array}{c}84 \pm \\
4.11 * *\end{array}$} & $\begin{array}{l}81 \pm \\
3.23\end{array}$ \\
\hline \multicolumn{10}{|c|}{ After Milking } \\
\hline Deoni (20) & $\begin{array}{c}76.33 \pm \\
4.05\end{array}$ & \multicolumn{2}{|c|}{$\begin{array}{c}77.66 \pm \\
4.26\end{array}$} & $\begin{array}{c}66.93 \pm \\
3.38\end{array}$ & $\begin{array}{l}72.1 \pm \\
4.15\end{array}$ & $\begin{array}{c}83.21 \pm \\
3.04\end{array}$ & \multicolumn{2}{|c|}{$\begin{array}{c}34.66 \pm \\
1.80\end{array}$} & $\begin{array}{c}46.33 \pm \\
3.63\end{array}$ \\
\hline $\begin{array}{c}\text { HF crossbred } \\
\text { (22) }\end{array}$ & $\begin{array}{l}84.5 \pm \\
3.36\end{array}$ & \multicolumn{2}{|c|}{$\begin{array}{c}75.15 \pm \\
4.04\end{array}$} & $\begin{array}{c}62.25 \pm \\
2.30\end{array}$ & $\begin{array}{c}75.25 \pm \\
2.57\end{array}$ & $\begin{array}{l}96.5 \pm \\
3.40 *\end{array}$ & \multicolumn{2}{|c|}{$\begin{array}{l}68.25 \pm \\
2.97 * *\end{array}$} & $\begin{array}{c}46.42 \pm \\
3.58\end{array}$ \\
\hline \multicolumn{10}{|c|}{$\begin{array}{l}(* \text { indicates significant difference between breeds }) \\
(* \text { significant at } \mathrm{P} \text {-value }=0.05, * *=\text { significant at } \mathrm{P} \text { value }=0.01)\end{array}$} \\
\hline \multicolumn{10}{|c|}{$\begin{array}{c}\text { Table.3 LS Mean } \pm \text { S.E of difference in teat measurement of Deoni and HF crossbreeds between } \\
\text { before and after milking }\end{array}$} \\
\hline \multirow[t]{2}{*}{ Breeds } & \multicolumn{7}{|c|}{$\begin{array}{c}\text { Difference in Teat Measurement between before and after milking } \\
(\mathbf{m m})\end{array}$} & \multirow{2}{*}{\multicolumn{2}{|c|}{$\begin{array}{c}\text { Mean test } \\
\text { day milk } \\
\text { yield }\end{array}$}} \\
\hline & FTL & FTD & RTL & RTD & DFT & DFRT & DRT & & \\
\hline Deoni (20) & $\begin{array}{l}8.11 \pm \\
1.077\end{array}$ & $\begin{array}{l}-1.14 \pm \\
0.623\end{array}$ & $\begin{array}{l}9.33 \pm \\
1.551\end{array}$ & $\begin{array}{r}-12.7 \pm \\
1.204\end{array}$ & $\begin{array}{l}-15.45 \pm \\
0.816\end{array}$ & $\begin{array}{l}-9.34 \pm \\
1.323\end{array}$ & $\begin{array}{c}-26.67 \pm \\
0.431\end{array}$ & & $12 \pm 0.89$ \\
\hline $\begin{array}{c}\text { HF crossbred } \\
\text { (22) }\end{array}$ & $\begin{array}{c}11.55 \pm \\
0.02\end{array}$ & $\begin{array}{l}-18.1 \pm \\
0.307 * *\end{array}$ & $\begin{array}{l}5.91 \pm \\
0.0301\end{array}$ & $\begin{array}{c}-19.5 \pm \\
0.139\end{array}$ & $\begin{array}{c}-36.5 \pm \\
0.21 *\end{array}$ & $\begin{array}{c}-15.75 \pm \\
0.28 *\end{array}$ & $\begin{array}{c}-34.58 \pm \\
0.15\end{array}$ & & $\begin{array}{c}9.94 \pm \\
0.66\end{array}$ \\
\hline
\end{tabular}

$(*=$ significant at $\mathrm{P}$-value $=0.05, * *=$ significant at $\mathrm{P}$ value $=0.01)$

Milk somatic cell count is indicative of total cell count per ml of milk collectively consists of milk epithelial cells, lymphocytes and blood cells (Rainard et al., 2018). Deoni's low SCC suggests it might have lesser incidence for mammary gland infection compared to HF crossbred cows, similar conclusion was observed from previous studies by Saravanan et al., (2014) and Mukunde et al., (2018).

Teat morphology are important for assess the 
milking rate, and incidence of mastitis, few studies says greater diameter of teat has positive correlation for higher incidence of mastitis in lactating animals as it has increased size of tip orifice (Kaur et al., 2018; Porcionato et al., 2010) significant difference in teat diameter between HF crossbred and Deoni could be morphological reason behind for its higher incidence of mastitis in crossbred in farm condition.. whereas similar in this study difference of distance between teats and front diameter before and after milking gives suggestive of higher milk holding of HF crossbred cows influence more mean test day milk yield but doesn't show any significant difference with mean test day milk yield of Deoni cattle which is similar to Minogoas et al., (2012) finding of teat length and diameter has lesser influence on milk yield in the Cameroon local and Holstein cows.

\section{Acknowledgement}

We sincerely thank Director of ICAR-NDRI, Head of Southern research station and Incharge of Livestock Research Centre, ICARNDRI Bengaluru.

\section{References}

Chandrasekar, T., Kalyan Sundar Das, Showkat A. Bhat, J. K. Singh, Thulasiraman Parkunanan, K. Puhle Japheth, Mayur R. Thul, and Pranay Bharti (2016). Relationship of prepartum udder and teat measurements with subsequent milk production traits in primiparous Nili-Ravi buffaloes. Veterinary world, 9(11): 1173.

Department of animal husbandry and Dairying (DAHD), http://dahd.nic.in/

Hand, K. J., Godkin, A. and Kelton, D. F. (2012). Milk production and somatic cell counts: a cow-level analysis. Journal of dairy science, 95(3): 1358-1362.
Joshi S, Gokhale S. Status of mastitis as an emerging disease in improved and periurban dairy farms in India. Ann. N. Y. Acad. Sci. 2006; 1081:74-83.

Kaur, G., Bansal, B. K., Singh, R. S., Kashyap, N., \& Sharma, S. (2018). Associations of teat morphometric parameters and subclinical mastitis in riverine buffaloes. Journal of Dairy Research, 85(3), 303-308

Mingoas, K. J. P., Awah-Ndukum, J., Dakyang, H., \& Zoli, P. A. (2017). Effects of body conformation and udder morphology on milk yield of zebu cows in North region of Cameroon. Veterinary world, 10(8), 901.

Mundhe, U. T., Das, D. N., Gandhi, R. S. and Divya, P. (2018). Studies on TLR2 gene variants and their association with milk yield and milk quality traits in Bos indicus (Deoni) cattle. Indian Journal of Animal Research, 52(2), 198-203.

National Dairy Development Board, https://www.nddb.coop/

Patel, Y. G., Trivedi, M. M., Rajpura, R. M., Savaliya, F. P. and Monika, P. (2016). Udder and teat measurements and their relation with milk production in crossbred cows. Int. J. Environ. Sci. Technol, 5(5): 3048-3054.

Porcionato, M. A. D. F., Soares, W. V. B., Reis, C. B. M. D., Cortinhas, C. S., Mestieri, L., \& Santos, M. V. D. (2010). Milk flow, teat morphology and subclinical mastitis prevalence in Gir cows. Pesquisa Agropecuária Brasileira, 45(12), 1507-1512

Rainard, P., Foucras, G., Boichard, D., \& Rupp, R. (2018). Invited review: low milk somatic cell count and susceptibility to mastitis. Journal of dairy science, 101(8), 6703-6714.

Saravanan R, Das DN, De S and Panneerselvam S. 2015. Effect of season and parity on somatic cell count across zebu and crossbred cattle population. 
Indian J. Anim. Res., 49 (3): 383-387.

Sinha K, Thombare NN, Mondal B. Subclinical mastitis in dairy animals: incidence, economics, and predisposing factors. Sci. WId. J. Available, 2014. doi.org/IO.1155/2014/523984.
(2005). Relationships between milk yield and udder measurements in Brown Swiss cows. Turkish Journal of Veterinary and Animal Sciences, 29(1): 75-81.

Tilki, M., İnal, S., Colak, M. and Garip, M.

\section{How to cite this article:}

Mohan, M., DN. Das, PB. Nandini and Ramesha, KP. 2020. Teat Morphological and Milk Somatic Cell Comparison between Zebu Cattle (Deoni) and HF Crossbred (Bos taurus x Bos indicus). Int.J.Curr.Microbiol.App.Sci. 9(07): 3243-3247.

doi: https://doi.org/10.20546/ijcmas.2020.907.378 